Brazilian Journal
of Chemical
Engineering

\title{
MOISTURE SORPTION CHARACTERISTICS OF MICROALGAE Spirulina platensis
}

\author{
E. G. Oliveira, G. S. Rosa, M. A. Moraes and L. A. A. Pinto* \\ Unit Operations Laboratory, School of Chemistry and Food, Universidade Federal do Rio Grande, FURG, \\ Phone: + (55) (53) 3233-8648, Fax: + (55) (53)3233-8745, P.O. Box 474, \\ Zip Code 96201-900, FURG, Rio Grande - RS, Brazil. \\ E-mail: dqmpinto@furg.br
}

(Submitted: April 13, 2008 ; Accepted: July 17, 2008)

\begin{abstract}
In recent times, the microalgae Spirulina platensis has been used as a functional ingredient in several food applications; its process involving drying and storage steps. Moisture equilibrium data for adsorption isotherms of microalgae Spirulina were investigated at 10,20 and $30^{\circ} \mathrm{C}$ and for desorption, at 40 , 50 and $60^{\circ} \mathrm{C}$, using the gravimetric static method. The experimental data were analyzed by GAB and BET models. The GAB equation showed the best fitting to the experimental data with $\mathrm{R}^{2} \approx 99 \%$ and $\mathrm{MRE}<10 \%$. The water surface area values calculated by GAB and BET models were very similar. The isosteric heats were determined by application of Clausius-Clapeyron equation to sorption isotherms obtained from the best-fitting equation. The isosteric heat and the entropy of desorption isotherm presented similar behavior, with a sharp change in an equilibrium moisture content of $10 \%$. The enthalpy-entropy compensation theory was applied to the isotherms, indicating that they are enthalpy-controlled.

Keywords: Spirulina platensis; Equilibrium isotherms; Heat of sorption; Differential entropy.
\end{abstract}

\section{INTRODUCTION}

Proteins are essential components of cells and biological process. They are involved in regulatory functions and in controlling intra and extracellular conditions. Production of photosynthetic microorganisms such as microalgae and cyanobacteria has been widely studied in biotechnology because such organisms have a very efficient biological system for harvesting solar energy for the production of organic compounds (Vonshak, 1997). From the microalgae and cyanobacteria that have been used as foodstuffs, food supplements and animal feed in many parts of the world, Spirulina platensis is the most popular. Spirulina is nowadays produced commercially by several companies around the world, and the product is mainly sold as a food supplement and animal feed (Belay et al., 1993). Spirulina has $62 \%$ amino acid content and is the world's richest natural source of vitamin $B_{12}$ and contains a whole spectrum of natural mixed carotene and xanthophyll phytopigments. Spirulina has a soft cell wall made of complex sugars and protein (Estrada et al., 2001). The high protein content makes of Spirulina platensis one of the richest protein sources, far greater than those of meat, fish or soybean meal (Melfi et al., 1997).

The most widely used control parameter for drying processes is the moisture content, and therefore an understanding of the relationship between water activity and moisture content is absolutely necessary to achieve optimal storage stability (Samapundo et al., 2007). Knowledge of the sorption isotherms is important for the design and optimization of the drying equipment, for the evaluation of air-food interface state in drying process simulation and, also, to determine the drying limit at given air conditions (Simal et al., 2007).

The isotherm curve can be obtained in one of two ways: adsorption or desorption. The adsorption and

*To whom correspondence should be addressed 
desorption processes are not fully reversible, then the system has hysteresis and therefore a distinction must be made between the isotherms by determining whether the moisture levels within the product are increasing or decreasing. The effect of temperature on the sorption isotherm is of great importance given that foods are exposed to a range of temperatures during storage and processing, and water activity changes with temperature. Temperature affects the mobility of the water molecules, and the dynamic equilibrium between the vapor and adsorbed phases (Al-Muhtaseb et al., 2004).

More than 200 equations have been proposed for modeling the equilibrium data, differing in their empirical or theoretical character, and in the number of parameters involved (Mulet et al., 2002). Models available in the literature to describe moisture sorption isotherm can be divided into several categories; kinetic models based on a monolayer (BET model), kinetic models based on a multi-layer and condensed film (GAB model), semi-empirical and empirical models (Al-Muhtaseb et al., 2004).

The thermodynamic properties of foods relate the concentration of water in food to its partial pressure, which is crucial in analysis of the heat and mass transport phenomena during dehydration. They determine the end-point to which the food must be dehydrated in order to achieve a stable product with optimal moisture content, and the minimum amount of energy required to remove a given amount of water from the food (Aviara and Ajibola, 2002). The properties also provide an insight into the microstructure associated with the food-water interface (Rizvi, 1995).

Enthalpy-entropy compensation theory is used to evaluate physical and chemical phenomena such as sorption reactions. The theory states that in order to minimize free energy changes due to these phenomena, compensation (by changing $\mathrm{q}_{\mathrm{st}}$ or $\mathrm{S}_{\mathrm{d}}$ ) arises from the nature of the interaction between the solute and solvent causing the reaction and that the relationship between the enthalpy and entropy for a specific reaction is linear (Fasina, 2006).

The use of Spirulina platensis as a functional ingredient is novel and very few sorption data are available in literature. Therefore, the aims of this work were: (a) to determine the adsorption and desorption isotherms of Spirulina platensis at 10, 20 and $30^{\circ} \mathrm{C}$ (storage temperatures) and 40,50 and $60^{\circ} \mathrm{C}$ (drying temperatures), respectively, (b) to evaluate GAB and BET models and compare their fit in describing the isotherms, (c) to determine thermodynamic functions such as the net isosteric heat of sorption and the differential entropy and (d) to evaluate the applicability of the enthalpy-entropy compensation theory to the adsorption and desorption phenomena.

\section{MATERIALS AND METHODS}

\section{Procedure}

Spirulina platensis LEB 52 (Costa et al., 2000) was cultivated in open photo-bioreactors, under uncontrolled conditions, in the south of Brazil. During these cultivations, water was supplemented with 20\% Zarrouk synthetic medium (Zarrouk, 1966), with an initial biomass concentration of 0.15 $\mathrm{gL}^{-1}$. Samples were taken every $24 \mathrm{~h}$ to determine the biomass concentration via optical density measurements at $670 \mathrm{~nm}$ (Costa et al., 2002). To recover the biomass the suspension of medium and algae was filtrated and then pressed. Spirulina moisture content was determined according to AOAC analytical norm (1995).

The equilibrium isotherms of Spirulina were determined at 10,20 and $30^{\circ} \mathrm{C}$ (storage temperatures) for adsorption and at 40,50 and $60^{\circ} \mathrm{C}$ (drying temperatures) for desorption. The gravimetric static method was applied. Spirulina samples dried in spouted bed were used on the experiments for the adsorption isotherms and on the experiments for the desorption isotherms wet Spirulina samples were used. The experiments to obtain the isotherms were carried on in glass jars, hermetically closed. Every jar was filled up to a quarter with various concentrations of sulfuric acid solutions $(0.20-0.70 \mathrm{~kg} / \mathrm{kg})$ to keep the water activity inside the bottles from 0.04 to 0.89 (Table 1), according to Perry and Green (1997). Three gram samples were weighed and placed on a support in each jar, not allowing contact with the acid solution. The jars were kept in an incubator, under controlled temperature during the time necessary to reach constant weight. Measures of the mass values were taken every two days in an electronic scale, with a precision of $0.001 \mathrm{~g}$. The equilibrium condition was reached when the difference among three consecutive measures was $\leq 0.001 \mathrm{~g}$, and in this condition the moisture content analysis was carried out in order to determine the equilibrium moisture content. Each experiment was carried out in triplicate. 
Table 1: Water activity values for the various sulfuric acid concentrations, at studied temperatures.

\begin{tabular}{|c|c|c|c|c|c|}
\hline \multicolumn{6}{|c|}{ Temperature } \\
\hline & $20^{\circ} \mathrm{C}$ & $30^{\circ} \mathrm{C}$ & $40^{\circ} \mathrm{C}$ & $50^{\circ} \mathrm{C}$ & $60^{\circ} \mathrm{C}$ \\
\hline Conc. $\mathrm{H}_{2} \mathrm{SO}_{4}\left(\mathrm{~kg} \mathrm{~kg}^{-1}\right)$ & \multicolumn{5}{|c|}{ Water activity $\left(a_{w}\right)$} \\
\hline 0.20 & 0.878 & 0.873 & 0.878 & 0.888 & 0.890 \\
\hline 0.25 & 0.816 & 0.817 & 0.824 & 0.829 & 0.830 \\
\hline 0.30 & 0.749 & 0.747 & 0.753 & 0.770 & 0.776 \\
\hline 0.35 & 0.665 & 0.666 & 0.674 & 0.681 & 0.682 \\
\hline 0.40 & 0.568 & 0.565 & 0.574 & 0.582 & 0.584 \\
\hline 0.45 & 0.458 & 0.461 & 0.470 & 0.483 & 0.488 \\
\hline 0.50 & 0.355 & 0.355 & 0.366 & 0.380 & 0.388 \\
\hline 0.55 & 0.258 & 0.260 & 0.267 & 0.280 & 0.287 \\
\hline 0.60 & 0.167 & 0.170 & 0.178 & 0.189 & 0.199 \\
\hline 0.65 & 0.093 & 0.097 & 0.102 & 0.110 & 0.124 \\
\hline 0.70 & 0.043 & 0.045 & 0.049 & 0.055 & 0.061 \\
\hline
\end{tabular}

Perry and Green (1997)

The equilibrium moisture data were fitted with $\mathrm{GAB}$ and BET models presented in Equations 1 and 2 , respectively.

$$
\begin{aligned}
& M e=\frac{M_{m} \cdot C_{G} \cdot k \cdot a_{w}}{\left(1-k \cdot a_{w}\right) \cdot\left(1-k \cdot a_{w}+C_{G} \cdot k \cdot a_{w}\right)} \\
& M e=\frac{M_{m} \cdot C_{B} \cdot a_{w}}{\left(1-a_{w}\right) \cdot\left(1-a_{w}+C_{B} \cdot a_{w}\right)}
\end{aligned}
$$

where: $M_{e}$ is equilibrium moisture content, $M_{m}$ is monolayer moisture content, $\mathrm{a}_{\mathrm{w}}$ is water activity and $\mathrm{C}_{\mathrm{G}}, \mathrm{C}_{\mathrm{B}}$ and $\mathrm{k}$ are adjustment parameters.

The BET constant $\mathrm{C}_{\mathrm{B}}$ is related logarithmically to the difference between the chemical potentials of the sorbate molecules in the pure liquid state and in the first sorption layer. On the other hand, the $\mathrm{GAB}$ constant $\mathrm{C}_{\mathrm{G}}$ is related to the difference of this magnitude between the upper layers and the monolayer, while the constant $\mathrm{k}$ is related to this difference between the pure liquid state of the sorbate and the upper layers, and the product of both $\left(\mathrm{C}_{\mathrm{G}} \times \mathrm{k}\right)$ represents the equivalent to $\mathrm{C}_{\mathrm{B}}$ of BET. It should be mentioned that the third GAB constant $\mathrm{k}$ was near to but less than unity, a fact which constitutes a definitive characteristic of this isotherm (Timmermann, 1989).

Nonlinear regression analysis, using the software Statistica for Windows 5.0 (Statsoft, USA), was used to estimate the constants of the models from the experimental data of isotherms.

Some years ago, the well-known BET sorption isotherm (Equation 2) was the most applied model for water sorption by foods and foodstuffs, although it was known to hold only for a limited range of water activity $\left(\mathrm{a}_{\mathrm{w}}\right)$, up to only $0.30-0.40$. In more recent years, the GAB isotherm equation (Equation 1) has been widely used to describe the sorption behavior of foods. Having a reasonable small number of parameters (three), the GAB equation has been found to represent adequately the experimental data in the range of water activity of most practical interest in foods (0.10-0.90) (Timmermann et al., 2001). The GAB model is considered to be the most versatile sorption model available in literature and is recommended by the European project COST 90 (Bizot, 1983).

The coefficient of determination, $\mathrm{R}^{2}$, was one of the primary criteria used for selecting the best equation to define the sorption curves of Spirulina platensis. In addition to $\mathrm{R}^{2}$, the suitability of the equations was also evaluated and compared using the mean relative error (MRE, \%), according to Equation 3 (Jamali et al., 2006).

$\operatorname{MRE}(\%)=\frac{100}{\mathrm{~N}}\left(\sum_{\mathrm{i}=1}^{\mathrm{N}} \frac{\mathrm{M}_{\mathrm{exp}}-\mathrm{M}_{\mathrm{cal}} /}{\mathrm{M}_{\exp }}\right)$

where: $N$ is the number of observations; $M_{\text {cal }}$ and $M_{\text {exp }}$ are the calculated and experimentally measured values of the equilibrium moisture content, respectively.

To evaluate the monolayer moisture contents $\left(\mathrm{M}_{\mathrm{m}}\right)$, the BET ( $\mathrm{a}_{\mathrm{w}}$ up to 0.4$)$ and GAB ( $\mathrm{a}_{\mathrm{w}}$ up to 0.9 ) models were used. Once the monolayer moisture content was known, the sorption surface area of Spirulina could be determined by the Equation 4 (Togrul and Arslan, 2007):

$\mathrm{S}_{\mathrm{o}}=\mathrm{M}_{\mathrm{m}} \frac{1}{\mathrm{PM}_{\mathrm{H}_{2} \mathrm{O}}} \mathrm{N}_{\mathrm{o}} \mathrm{A}_{\mathrm{H}_{2} \mathrm{O}}=3.5 \times 10^{3} \mathrm{M}_{\mathrm{m}}$

where $\mathrm{S}_{0}$ is the surface area $\left(\mathrm{m}^{2} \mathrm{~g}^{-1}\right), \mathrm{M}_{\mathrm{m}}$ is the monolayer moisture content, $\mathrm{PM}_{\mathrm{H} 2 \mathrm{O}}$ is the molecular weight of water $\left(18 \mathrm{~g} \mathrm{~mol}^{-1}\right), \mathrm{N}_{0}$ is the number of Avogadro $\left(6 \times 10^{23}\right.$ molecules $\left.\mathrm{mol}^{-1}\right)$ and $\mathrm{A}_{\mathrm{H} 2 \mathrm{O}}$ is the area of one water molecule $\left(10.6 \times 10^{-20} \mathrm{~m}^{2}\right)$. 
The isosteric heats of sorption for specific moisture content were derived from Clausius-Clapeyron equation (Equation 5) (Tolaba et al., 2003).

$$
\mathrm{q}_{\mathrm{st}}=-\mathrm{R}\left[\frac{\mathrm{d}\left(\ln \mathrm{a}_{\mathrm{w}}\right)}{\mathrm{d}(1 / \mathrm{T})}\right]_{\mathrm{x}}
$$

where: $\mathrm{q}_{\mathrm{st}}$ is the net isosteric heat of sorption in $\mathrm{kJ} \mathrm{mol}^{-}$ ${ }^{1} ; \mathrm{a}_{\mathrm{w}}$ is the water activity; $\mathrm{R}$ is the universal gas constant $\left(8.314 \mathrm{~J} \mathrm{~mol}^{-1} \mathrm{~K}^{-1}\right)$; T is the temperature in $\mathrm{K}$.

Net isosteric heats $\left(\mathrm{q}_{\mathrm{st}}\right)$ and the differential entropy $\left(S_{d}\right)$ of sorption at each moisture content were obtained by fitting Equation 6 to equilibrium data from the best-fitting equation (Madamba et al., 1996).

$-\ln \mathrm{a}_{\mathrm{w}}=\frac{\mathrm{q}_{\mathrm{st}}}{\mathrm{RT}}-\frac{\mathrm{S}_{\mathrm{d}}}{\mathrm{R}}$

According to the compensation theory, the linear relationship between enthalpy and entropy for a specific reaction is given by Equation 7 .

$\mathrm{q}_{\mathrm{st}}=\mathrm{T}_{\beta} \mathrm{S}_{\mathrm{d}}+\Delta \mathrm{G}_{\beta}$

The isokinetic temperature, $T_{\beta}$, represents the temperature at which all reactions in the series proceed at the same rate, and the free energy at $T_{\beta}$, $\Delta \mathrm{G}_{\beta}$, provides a criterion to evaluate if water sorption is a spontaneous $\left(-\Delta \mathrm{G}_{\beta}\right)$ or non spontaneous process $\left(+\Delta \mathrm{G}_{\beta}\right)$.

To test the validity of the compensation theory, the isokinetic temperature should be compared with the harmonic mean temperature $\left(\mathrm{T}_{\mathrm{hm}}\right)$ (Equation 8). Thus, a linear compensation pattern only exists if $\mathrm{T}_{\beta}$ $\neq \mathrm{T}_{\mathrm{hm}}$ (Simal et al., 2007).

$$
\mathrm{T}_{\mathrm{hm}}=\frac{\mathrm{n}_{\mathrm{i}}}{\sum_{\mathrm{i}=1}^{\mathrm{n}_{\mathrm{i}}} 1 / \mathrm{T}}
$$

where: $\mathrm{n}_{\mathrm{i}}$ is the total number of isotherms. Moreover, if $T_{\beta}>T_{h m}$ the process is enthalpy driven, while if the opposite condition is observed $\left(\mathrm{T}_{\beta}<\mathrm{T}_{\mathrm{hm}}\right)$, the process is considered to be entropy-controlled.

\section{RESULTS AND DISCUSSION}

Figures 1 and 2 present the experimental data obtained of the moisture content of the Spirulina at different temperatures as a function of $a_{w}$ for adsorption and desorption, respectively. The initial moisture contents of Spirulina samples for the experiments to obtain the desorption and adsorption isotherms were $76.7 \pm 0.6$ and $6.6 \pm 0.2 \%$ (wet basis), respectively.

The adsorption and desorption isotherms presented a sigmoid shape, also classified as $\mathrm{S}$ isotherm (Hinz, 2001). The adsorption and desorption isotherms indicated that equilibrium moisture content increased with increasing water activity at constant temperature. These changes in equilibrium moisture content are due to the inability of the foodstuff to maintain vapor pressure at unity with decreasing moisture content. As moisture content decreases, moisture in the food tends to show a lower vapor pressure, acting as if in solution, changing with atmospheric humidity. These changes in vapor pressure with atmospheric humidity in food result in the characteristic sigmoid shape of water sorption isotherms (Togrul and Arslan, 2006). The sorption isotherms obtained have a sigmoid shape of type II, according to BET classification (Iglesias and Chirife, 1982).

There was an increase in moisture content with decreasing temperatures. As temperature varies, the excitation of molecules as well as the distance, and thus the attraction between molecules varies (AlMuhtaseb et al., 2004). This causes the amount of sorbed water to change with temperature at a given water activity.

The GAB and BET models were fitted to the experimental data at the studied temperatures in order to determine the best model to predict the sorption isotherm for the product being studied. The results obtained are presented in Tables 2 and 3, for adsorption and desorption, respectively. The constants obtained for each equation, the coefficients of determination $\left(\mathrm{R}^{2}\right)$ and the mean relative error (MRE) are presented in those tables.

In Tables 2 and 3 the GAB model shows the best coefficients of determination $\left(\mathrm{R}^{2}>98 \%\right)$ and low mean relative error $(\mathrm{MRE} \%<10 \%)$. The monolayer moisture content $\left(\mathrm{M}_{\mathrm{m}}\right)$, represents the moisture content of the material when the entire surface is covered with a unimolecular moisture layer and the optimum moisture content for maximum shelf stability may be determined (Ariahu et al., 2006). Tables 2 and 3 show that the monolayer moisture contents in GAB were mildly higher than in BET model, and the $\mathrm{Mm}$ values decreased when temperature increased in both models. The monolayer moisture contents of the desorption isotherms were higher than the values of the adsorption isotherms due the hysteresis.

The physical structure and solid surface area play an important role in determining the water binding properties of foodstuff. The values for surface area, calculated from Equation 4, using the monolayer moisture contents evaluated by the GAB and the BET models, are presented in Table 4. 


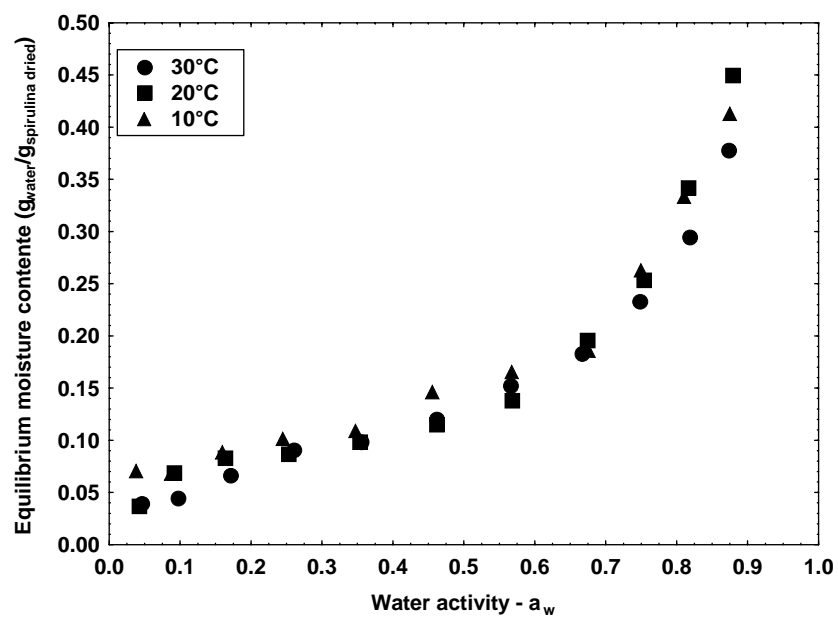

Figure 1: Adsorption isotherms of Spirulina, average values (triplicates)



Figure 2: Desorption isotherms of Spirulina, average values (triplicates)

Table 2: Estimated parameters, $R^{2}$ and MRE values of the equations for the adsorption isotherms.

\begin{tabular}{|c|c|c|c|c|c|c|}
\hline Eq & $\mathrm{T}\left({ }^{\circ} \mathrm{C}\right)$ & \multicolumn{3}{|c|}{ Constants $^{\mathrm{a}}$} & $\mathbf{R}^{2}$ & MRE \\
\hline 1 & 10 & $\mathrm{M}_{\mathrm{m}}=0.082 \pm 0.003$ & $\mathrm{C}_{\mathrm{G}}=84.74 \pm 42.39$ & $\mathrm{k}=0.92 \pm 0.008$ & 0.986 & 0.051 \\
\hline & 20 & $\mathrm{M}_{\mathrm{m}}=0.073 \pm 0.001$ & $\mathrm{C}_{\mathrm{G}}=44.71 \pm 13.49$ & $\mathrm{k}=0.97 \pm 0.004$ & 0.993 & 0.077 \\
\hline & 30 & $\mathrm{M}_{\mathrm{m}}=0.069 \pm 0.002$ & $\mathrm{C}_{\mathrm{G}}=17.24 \pm 1.94$ & $\mathrm{k}=0.92 \pm 0.004$ & 0.998 & 0.045 \\
\hline $2^{\mathrm{b}}$ & 10 & $\mathrm{M}_{\mathrm{m}}=0.080 \pm 0.002$ & $C_{B}=89.67 \pm 40.69$ &  & 0.903 & 0.057 \\
\hline & 20 & $\mathrm{M}_{\mathrm{m}}=0.071 \pm 0.002$ & $C_{B}=49.75 \pm 15.17$ & $\ldots$ & 0.883 & 0.111 \\
\hline & 30 & $\mathrm{M}_{\mathrm{m}}=0.067 \pm 0.002$ & $C_{B}=16.26 \pm 2.11$ & $\ldots$ & 0.979 & 0.067 \\
\hline
\end{tabular}

${ }^{a}$ The values are means \pm standard deviation, $(n=3)$.

${ }^{\mathrm{b}}$ Water activity range for BET was 0.05-0.40.

Table 3: Estimated parameters, $R^{2}$ and MRE values of the equations for the desorption isotherms.

\begin{tabular}{|c|c|c|c|c|c|c|}
\hline Eq & $\mathrm{T}\left({ }^{\circ} \mathrm{C}\right)$ & \multicolumn{3}{|c|}{ Constants $^{\mathrm{a}}$} & $\mathbf{R}^{2}$ & MRE \\
\hline 1 & 40 & $\mathrm{M}_{\mathrm{m}}=0.129 \pm 0.003$ & $\mathrm{C}_{\mathrm{G}}=55.61 \pm 23.76$ & $\mathrm{k}=0.959 \pm 0.006$ & 0.990 & 0.065 \\
\hline & 50 & $\mathrm{M}_{\mathrm{m}}=0.110 \pm 0.002$ & $\mathrm{C}_{\mathrm{G}}=37.42 \pm 10.95$ & $\mathrm{k}=0.945 \pm 0.005$ & 0.994 & 0.054 \\
\hline & 60 & $\mathrm{M}_{\mathrm{m}}=0.068 \pm 0.002$ & $\mathrm{C}_{\mathrm{G}}=35.19 \pm 20.44$ & $\mathrm{k}=0.944 \pm 0.008$ & 0.986 & 0.085 \\
\hline $2^{\mathrm{b}}$ & 40 & $\mathrm{M}_{\mathrm{m}}=0.122 \pm 0.003$ & $\mathrm{C}_{\mathrm{B}}=53.82 \pm 16.82$ & 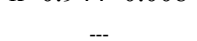 & 0.954 & 0.058 \\
\hline & 50 & $\mathrm{M}_{\mathrm{m}}=0.103 \pm 0.003$ & $\mathrm{C}_{\mathrm{B}}=38.68 \pm 55.36$ & $\ldots$ & 0.915 & 0.068 \\
\hline & 60 & $\mathrm{M}_{\mathrm{m}}=0.066 \pm 0.003$ & $\mathrm{C}_{\mathrm{B}}=24.35 \pm 11.94$ & -- & 0.890 & 0.095 \\
\hline
\end{tabular}

${ }^{\mathrm{a}}$ The values are means \pm standard deviation, $(\mathrm{n}=3)$.

${ }^{\mathrm{b}}$ Water activity range for BET was 0.05-0.40. 
Table 4: Surface area values calculated by GAB and BET models, for adsorption and desorption.

\begin{tabular}{|c|c|c|c|}
\hline \multirow{2}{*}{} & & \multicolumn{2}{|c|}{ Surface area $\left(\mathbf{m}^{2} / \mathbf{g}\right)$} \\
\cline { 2 - 4 } & $\left.\mathbf{T ~} \mathbf{}^{\circ} \mathbf{C}\right)$ & GAB & 280.0 \\
\hline \multirow{3}{*}{ Adsorption } & 10 & 287.0 & 248.5 \\
& 20 & 255.5 & 234.5 \\
\hline \multirow{2}{*}{ Desorption } & 30 & 241.5 & 427.0 \\
& 40 & 451.5 & 360.5 \\
\end{tabular}

The results presented in Table 4 indicate that the total surface area available for hydrophilic binding in adsorption and desorption decreased with increasing temperature. The large surface area of many biopolymers is due to the existence of an intrinsic microporous structure in those materials (Calzetta Resio et al., 2000). Table 4 also shows that the water surface area for the GAB and BET models were very similar. The surface area values calculated were in the range obtained by Arslan and Togrul, (2005) for desorption macaroni at $25-45^{\circ} \mathrm{C}\left(373-380 \mathrm{~m}^{2} \mathrm{~g}^{-1}\right)$ and Tolaba et al. (2004) for desorption quinoa grains at different temperatures $\left(200-350 \mathrm{~m}^{2} \mathrm{~g}^{-1}\right)$.

The thermodynamic functions are readily calculated from sorption isotherms enabling the interpretation of experimental results in accordance with the statement of the theory (Iglesias et al., 1976). The functions include net isosteric heat of sorption and differential entropy. The net isosteric heat of sorption, or enthalpy $\left(\mathrm{q}_{\mathrm{st}}\right)$, provides a measure of the energy variations occurring when water molecules mix with sorbent during sorption processes. The heat of adsorption is a measure of the energy released during sorption, and the heat of desorption of the energy requirement to break the intermolecular forces between the molecules of water vapor and the surface of adsorbent (Rizvi, 1995). Thus, the heat of sorption is considered an indicative of the intermolecular attractive forces between the sorption sites and water vapor (Wang and Brennan, 1991).

Differential entropy $\left(S_{d}\right)$ may be associated with the binding or repulsive forces in the system and is associated with the spatial arrangements at the watersorbent interface. Thus, entropy characterizes or defines the degree of order or randomness existing in the water-sorbent system and aids interpretation of processes such as dissolution, crystallization and swelling. Free energy $(\Delta \mathrm{G})$ indicates the affinity of the sorbent for water, and its sign provides a criterion as to whether water sorption is a spontaneous $(-\Delta \mathrm{G})$ or non-spontaneous process $(+\Delta \mathrm{G})$ (McMinn et al., 2005).

The net isosteric heats of adsorption and desorption of water at each moisture content were determined by applying Equation 6 to data calculated by using the GAB equation. The variation in net heats of adsorption and desorption, $\mathrm{q}_{\mathrm{st}}$, of Spirulina with moisture content are shown in Figure 3.

Net isosteric heats of desorption increased to a maximum and then decreased with the increase in moisture content. The maximum isosteric heat of desorption was obtained with a moisture content of $10 \%$ dry basis. The maximum enthalpy value indicates the covering of the strongest binding sites and the greatest water-solid interaction. Covering of less favorable locations and formation of multi-layers follow then, as shown by the decrease in enthalpy with increasing moisture content. Net isosteric heats of adsorption decreased with the increase in moisture content and the trend seemed to become asymptotic as a moisture content of $15 \%$ (d.b.) was approached. This confirms the fact that at higher moisture levels, the strength of water binding decreases. Different polar groups on the water binding polymers in foods and changes in the dimensions and geometry of the polymers during sorption are thought to give rise to this range of activity in sorption sites (McLaughlin and Magee, 1998).

The sorption entropy obtained by fitting Equation 6 with moisture content is shown in Figure 4.

The desorption entropy decreased to a minimum and then increased with an increase in moisture content (Figure 4). The adsorption entropy increased with increasing moisture content to the maximum value and did not change thereafter. The decrease of entropy in the low water activity range for desorption was attributed to the lateral interaction in the adsorbed film caused by restrictive effect (loss of rotational freedom) of the adsorbed water molecules as the available sites become saturated. Sorption entropy is proportional to the number of available sorption sites at a specific energy level. The entropy values were negative in magnitude for all moisture content range. Iglesias et al. (1976) attributed the negative entropy values to the existence of chemical adsorption and/or structural modifications of the adsorbent. Rizvi (1986) attributed it to the fact that the products contain more polar groups, which bind water more strongly.

The plot of $\mathrm{q}_{\mathrm{st}}$ versus $\mathrm{S}_{\mathrm{d}}$ for Spirulina is shown in Figure 5. A linear relationship was exhibited with coefficients of determination $\mathrm{R}^{2}$ of 0.999 . Thus, the results confirm the compensation theory. 
The isokinetic temperature $\left(T_{\beta}\right)$ and free energy $(\Delta \mathrm{G})$ (Equation 7), determined by linear regression in Figure 5, for adsorption and desorption, were of $336.8 \mathrm{~K}$ and $0.906 \mathrm{~kJ} / \mathrm{mol}$ and $355.3 \mathrm{~K}$ and 0.166 $\mathrm{kJ} / \mathrm{mol}$, respectively. The calculated harmonic mean temperatures (Equation 8) were 292.8K for adsorption and $322.8 \mathrm{~K}$ for desorption, values different to the isokinetic temperature values, confirming the suitability of the isokinetic theory for water sorption of Spirulina. Furthermore, $\mathrm{T}_{\beta}>$ $\mathrm{T}_{\mathrm{hm}}$, indicating an enthalpy controlled sorption process.

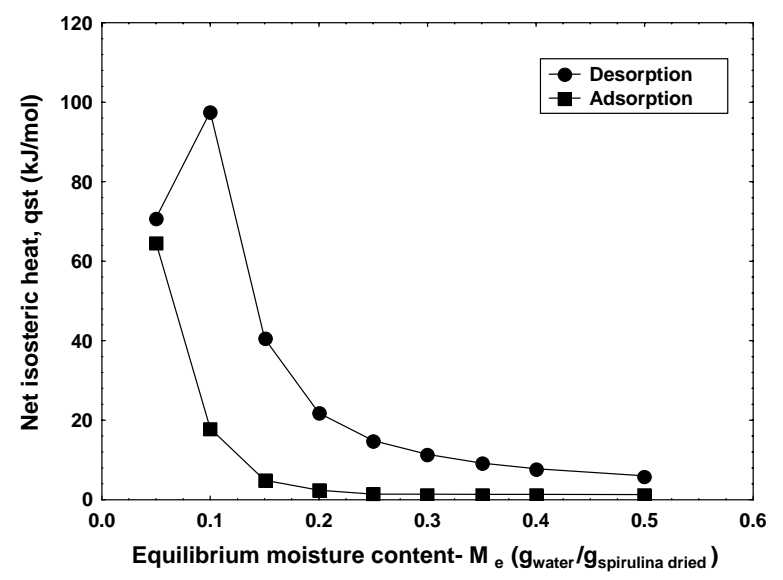

Figure 3: Net isosteric heats of sorption as a function of moisture content



Figure 4: Differential entropy of adsorption and desorption with moisture content



Figure 5: Net isosteric heat and differential entropy relation for adsorption and desorption. 


\section{CONCLUSIONS}

The best fits were obtained with the GAB equation for the experimental moisture adsorption/desorption isotherm data of Spirulina platensis for the temperatures and the water activity ranges studied $\left(\mathrm{R}^{2} \approx 99 \%\right.$ and $\left.\mathrm{MRE}<10 \%\right)$. Monolayer moisture contents $\left(\mathrm{M}_{\mathrm{m}}\right)$ and surface areas calculated from $\mathrm{M}_{\mathrm{m}}$ values decreased with increasing temperature. The water surface area values calculated by GAB and BET models were very similar.

Isosteric heats decreased with the increase of moisture content and approached the latent heat of pure water. The entropies increased with increasing moisture content. The isosteric heat and the entropy of desorption isotherm presented similar behavior, with a sharp change in an equilibrium moisture content of $10 \%$. Enthalpy-entropy compensation theory could be successfully applied to moisture adsorption and desorption behaviors of Spirulina, indicating an enthalpy controlled process.

\section{ACKNOWLEDGMENTS}

The authors would like to acknowledge the financial support of Brazilian agencies CAPES and FAPERGS.

\section{NOMENCLATURE}

\begin{tabular}{|c|c|}
\hline$a_{w}$ & water activity \\
\hline $\mathrm{A}_{\mathrm{H} 2 \mathrm{O}}$ & area of one water molecule \\
\hline $\mathrm{C}_{\mathrm{B}}$ & constant in equation (2) \\
\hline $\mathrm{C}_{\mathrm{G}}$ & constant in equation (1) \\
\hline$\Delta \mathrm{G}_{\beta}$ & free energy at $T_{\beta}$ \\
\hline $\mathrm{k}$ & constant in equation (1) \\
\hline MRE & mean relative error \\
\hline $\mathrm{Me}$ & $\begin{array}{l}\text { equilibrium moisture } \\
\text { content of the sample (d.b.) }\end{array}$ \\
\hline $\mathrm{M}_{\mathrm{cal}}$ & $\begin{array}{l}\text { calculated equilibrium } \\
\text { moisture content }\end{array}$ \\
\hline $\mathrm{M}_{\exp }$ & $\begin{array}{l}\text { experimental equilibrium } \\
\text { moisture content }\end{array}$ \\
\hline $\mathrm{M}_{\mathrm{m}}$ & $\begin{array}{l}\text { monolayer moisture content } \\
\text { of the sample (d.b.) }\end{array}$ \\
\hline$n_{i}$ & number of isotherms \\
\hline $\mathrm{N}$ & $\begin{array}{l}\text { number of experimental } \\
\text { points }\end{array}$ \\
\hline $\mathrm{N}_{0}$ & number of Avogadro \\
\hline & molecular weight of $\mathrm{w}$ \\
\hline
\end{tabular}

dimensionless $\mathrm{m}^{2}$ dimensionless dimensionless $\mathrm{kJ} \mathrm{mol}^{-1}$ dimensionless $\mathrm{kg} \mathrm{kg}^{-1}$ $\mathrm{kg} \mathrm{kg}^{-1}$ $\mathrm{kg} \mathrm{kg}^{-1}$ $\mathrm{kg} \mathrm{kg}^{-1}$

dimensionless dimensionless

molecules $\mathrm{mol}^{-1}$ $\mathrm{g} \mathrm{mol}^{-1}$

$\begin{array}{ll}\mathrm{q}_{s t} & \text { net isosteric heat of sorption } \\ \mathrm{R} & \text { universal gas constant } \\ \mathrm{S}_{0} & \text { surface area } \\ \mathrm{S}_{\mathrm{d}} & \text { differential entropy } \\ \mathrm{T} & \text { temperature } \\ \mathrm{T}_{\beta} & \text { isokinetic temperature } \\ \mathrm{T}_{\mathrm{hm}} & \text { harmonic mean temperature }\end{array}$

$\mathrm{kJ} \mathrm{mol}^{-1}$
$\mathrm{~kJ} \mathrm{~mol}^{-1} \mathrm{~K}^{-1}$
$\mathrm{~m}^{2} \mathrm{~g}^{-1}$
$\mathrm{~kJ} \mathrm{~mol}^{-1} \mathrm{~K}^{-1}$
$\mathrm{~K}$
$\mathrm{~K}$
$\mathrm{~K}$

\section{REFERENCES}

Association of Official Analytical Chemists (AOAC), Official Methods of Analysis 16th ed., v.1. Published by AOAC International, Arlington/USA (1995).

Al-Muhtaseb, A. H., Mcminn, W. A. M. and Magee T. R. A., Water sorption isotherms of starch powders. Part 1: mathematical description of experimental data. Journal of Food Engineering, 61, p. 297 (2004).

Aviara, N. A. and Ajibola, O. O., Thermodynamics of moisture sorption in melon seed and cassava. Journal of Food Engineering, 55, p. 07 (2002).

Ariahu, C. C., Kaze, S.A. and Achem, C. D., Moisture sorption characteristics of tropical fresh water crayfish (Procambarus clarkii). Journal of Food Engineering, 75, p. 355 (2006).

Arslan, N. and Togrul, H., Modelling of water sorption isotherms of macaroni stored in chamber under controlled humidity and thermodynamics approach. Journal of Food Engineering, 69, p. 133 (2005)

Belay, A., Ota, Y., Miyakawa, K. and Shimamatsu, H., Current knowledge on potential health benefits of Spirulina. Journal Applied Phycology, 5, p. 235 (1993).

Bizot, H., Using the GAB model to construct sorption isotherms. In: Jowitt et al. (ed), Physical properties of foods. p. 43. New York, USA: Applied Science (1983).

Calzetta Resio, A. N., Tolaba, M. P. and Suarez C., Some physical and thermal characteristics of amaranth starch. Food Science Technology International, 6, p. 371 (2000).

Costa, J. A. V., Linde, G. A., Atala, D. I. P., Mibileli G. M. and Krüger, R. T., Modelling of growth conditions for cyanobacterium Spirulina platensis in microcosms. World Journal Microbiology Biotechnology, 16, p. 15 (2000).

Costa, J. A. V., Colla, L. M., Duarte P. F., Kabke K. and Weber A., Modelling of Spirulina platensis growth in fresh water using response surface methodology. World Journal Microbiology Biotechnology, 18, p. 603 (2002). 
Estrada, J. E. P., Bermejo Bescòs, P. and Villar Del Fresno, A. M., Antioxidant activity of different fractions of Spirulina platensis protean extract. IL Farmaco, 56, p. 497 (2001).

Fasina, O. O. Thermodynamic properties of sweetpotato. Journal of Food Engineering, 75, 149 (2006).

Hinz, C., Description of sorption data with isotherm equations. Geoderma, 99, p. 225 (2001).

Iglesias, H. A. and Chirife, J., Handbook of food isotherms, p. 170. New York, USA: Academic Press (1982).

Iglesias, H. A., Chirife, J. and Viollaz, P., Thermodynamics of water vapour sorption by sugar beet root. Journal Food Technology, 11, p. 91 (1976).

Jamali, A., Kouhila, M., Ait Mohamed, L., Jaouhari, J. T., Idlimam, A. and Abdenouri, N. Sorption isotherms of Chenopodium ambrosioides leaves at three temperatures. Journal of Food Engineering, 72, p. 77 (2006).

Madamba, P. S., Driscoll, R. H. and Buckle K. A., Enthalpy-entropy compensation models for sorption and browning of garlic. Journal of Food Engineering, 28, p. 109 (1996).

Mclaughlin, C. P. and Magee, T. R. A., The determination of sorption isotherm and the isosteric heats of sorption for potatoes. Journal of Food Engineering, 35, p. 267 (1998).

McMinn, W. A. M., AL-Muhtaseb, A. H. and Magee, T. R. A., Enthalpy-entropy compensation in sorption phenomena of starch materials. Food Research International, 38, p. 505 (2005).

Melfi, D., Balestreri, E., Felicioli, R., Fiorentini, R. and Tomaselli, L., Structural and functional characteristics of ribulose-1,5-bisphosphate carboxylase from Spirulina platensis. Lebensm.Wiss. Technology, 30, p. 616 (1997).

Mulet, A., Garcia-Pascual, P., Sanjúan, N. and Garcia-Reverter, J., Equilibrium isotherms and isosteric heat of morel (Morchella esculenta). Journal of Food Engineering, 53, p. 75 (2002).

Perry, R. H. and Green, D. W., Perry's Chemical Engineers' Handbook. $7^{\text {th }}$ edition. McGraw-Hill, New York, (1997).

Rizvi, S. S. H., Thermodynamics of foods in dehydration. In: Rao, M. A. \& Rizvi, S. S. H (Eds), Engineering Properties of Food, p. 133, Marcel Dekker Inc, New York. (1986).

Rizvi, S. S. H., Thermodynamic properties of food in dehydration. In: Rao, M. A. \& Rizvi, S. S. H (Eds), Engineering Properties of Food, p. 223. Marcel Dekker Inc, New York (1995).

Samapundo, S., Devlieghere, F., Meulenaer, B., Atukwase, A., Lamboni, Y. and Debevere, J. M. Sorption isotherms and isosteric heats of sorption of whole yellow dent corn. Journal of Food Engineering, 79, p. 168 (2007).

Simal, S., Femenia, A., Castell-Palou, A. and Rosselló, C., Water desorption thermodynamic properties of pineapple. Journal of Food Engineering, 80, p. 1293 (2007).

Timmermann E. O., A BET-like three sorption stage isotherm. Journal of Chemical Society Faraday Transactions. 85, p. 1631 (1989).

Timmermann, E. O., Chirife, J. and Iglesias, H. A., Water sorption isotherms of foods and foodstuffs: BET or GAB parameters? Journal of Food Engineering, 48, p. 19 (2001).

Togrul, H. and Arslan, N., Moisture sorption behaviour and thermodynamic characteristics of rice stored in a chamber under controlled humidity. Biosystems Engineering, 95, p. 181 (2006).

Togrul, H., and Arslan, N., Moisture sorption isotherms and thermodynamic properties of walnut kernels. Journal Stored Products Research, 43, p. 252 (2007).

Tolaba, M. P., Peltzer, M., Enriquez, N. and Pollio, M. L., Grain sorption equilibria of quinoa grains. Journal Food Engineering, 61, p. 365 (2004).

Vonshak, A., Spirulina platensis (Arthospira): Physiology, cell biology and biotechnology. Taylor \& Francis, London (1997).

Wang, N. and Brennan, J. G., Moisture sorption isotherm characteristics of potatoes at four temperatures. Journal of Food Engineering, 14, p. 269 (1991).

Zarrouk, C., Contribution a L'étude D'une Cyanophycée. Influence de Díves Facteurs Physiques et Chimiques sur la Croissance et Photosynthese de Spirulina maxima geitler, Ph.D thesis, University of Paris (1966). 